\title{
DISPOSISI MATEMATIS SISWA SMK BERDASARKAN LANGKAH- LANGKAH PENYELESAIAN MASALAH POLYA
}

\author{
Habibah Nur Jannah \\ Universitas Nusantara PGRI Kediri, habibnur18@gmail.com \\ Received : 25 Mei 2019, Revised : 19 September 2019, Accepted : 23 April 2020 \\ (C) Mathematics Education Unugiri 2020
}

\begin{abstract}
This study aims to analyze the mathematical disposition of vocational students. The research model used is descriptive qualitative. Mathematical disposition is the ability of students to solve problems in mathematics. Mathematical disposition is important for students in everyday life. But there are still many difficulties encountered by students in solving problems. This was evidenced when the researcher carried out a preliminary study at the Kediri Vocational High School PGRI, which found that some students were less able to solve mathematical problems with confidence, as well as other indicators that showed weak mathematical dispositions. This is reinforced by the teacher's statement that in addition to the weak concept being mastered, students lack confidence in solving math problems given by the teacher. Based on these problems, researchers are interested in knowing more about the disposition of mathematics students given mathematical problems whose results are resolved based on the steps to solve problems according to Polya's theory. This study aims to describe students' mathematical dispositions based on problem solving steps. The instruments used are student worksheets and interview sheets. The subjects of this study were students of class XI of Hidayatus Sholihin Vocational School, who were capable of the Department of Computer and Network Engineering. The results of the trial show that students with moderate mathematical abilities have different mathematical dispositions, namely moderate and low. Students who are capable of going through 3 steps to solve the problem, while the low ability can only do 1 step.
\end{abstract}

Keywords: mathematical disposition, problem solving, polya, batik

Abstrak

Penelitian ini bertujuan untuk menganalisis disposisi matematis siswa SMK. Model penelitian yang digunakan adalah deskriptif kualitatif. Disposisi matematis adalah kemampuan siswa dalam menyelesaikan permasalahan dalam matematika. Disposisi matematis penting bagi siswa dalam kehidupan sehari-hari. Namun masih banyak dijumpai kesulitan siswa dalam menyelesaikan masalah. Hal ini dibuktikan ketika peneliti melaksanakan studi pendahuluan di SMK PGRI Kediri yaitu didapati beberapa siswa kurang mampu menyelesaikan masalah matematika dengan percaya diri, serta indikator lain yang menunjukkan disposisi matematisnya lemah. Hal ini diperkuat dengan penyataan guru bahwa selain lemahnya konsep yang dikuasai, siswa kurang percaya diri dalam menyelesaikan masalah matematika yang diberikan oleh guru. Berdasarkan masalah tersebut, peneliti tertarik untuk mengetahui lebih lanjut disposisi matematika siswa dengan diberikan masalah matematika yang hasilnya penyelesaian masalahnya dikaji berdasarkan langkah-langkah penyelesaian masalah menurut teori Polya. Penelitian ini bertujuan untuk mendeskripsikan disposisi matematis siswa berdasarkan langkah penyelesaian masalah. Instrumen yang dipergunakan adalah lembar kerja siswa dan lembar wawancara. Subjek penelitian ini adalah siswa kelas XI SMK Hidayatus Sholihin Jurusan Teknik Komputer dan Jaringan yang berkemampuan sedang. Hasil Uji coba menunjukkan siswa berkemampuan matematis sedang memiliki disposisi matematis yang berbeda, yakni sedang dan rendah. Siswa berkemampuan sedang melewati 3 langkah penyelesaian masalah, sedangkan kemampuan rendah mampu hanya melakukan 1 langkah.

Kata kunci: disposisi matematis, penyelesaian masalah, polya, batik 


\section{Pendahuluan}

Dalam pembelajaran matematika, siswa tidak akan pernah lepas dari menyelesaikan masalah. Ketika berusaha menyelesaikan masalah, dibutuhkan rasa ingin tahu pada masalah tersebut, kegigihan dalam menyelesaikan, tekun dalam mengerjakan, fleksibel dengan ilmu pengetahuan yang dimiliki, dan kepercayaan diri dengan cara yang digunakan untuk menyelesaikan permasalahan. Sikap-sikap ini merupakan indikator disposisi matematis.

Matematika adalah mata pelajaran yang mengajarkan cara berfikir sistematis dan terstruktur. National Council of Teachers of Mathematics (NCTM) [1], menetapkan standar-standar kemampuan matematis seperti pemecahan masalah, penalaran dan pembuktian, komunikasi, koneksi, dan representasi, seharusnya dapat dimiliki oleh peserta didik.

Matematika di sekolah menengah kejuruan diharap mampu memberi kesadaran para siswa akan pentingnya matematika untuk dipahami, matematika adalah pelajaran yang berguna, serta dengan ketekunan dan keuletan dalam matematika jika dipelajari dengan sungguh-sungguh akan membuahkan hasil yang bermanfaat. Namun di sisi lain, matematika menjadi pelajaran yang dianggap sulit bagi siswa SMK dalam menyelesaikan masalah secara terstruktur. Hal tersebut selaras dengan hasil ujian nasional tahun pelajaran 2017/2018. Kepala Badan Penelitian dan Pengembangan, Kemendikbud, Totok Suprayitno, mengatakan bahwa secara umum terjadi penurunan rerata nilai $U N$, terutama untuk mapel matematika, fisika, dan kimia. [2].

Salah satu indikator diposisi matematis yang disebutkan NCTM adalah kemampuan menyelesaikan masalah atau problem solving. Maka dari itu, disposisi matematis sangat mempengaruhi keberhasilan belajar matematika.

Berdasarkan hasil wawancara dengan salah satu guru matematika kelas XI di SMK PGRI 2 Kota Kediri, ketika pelaksanaan studi pendahuluan pada 1-15 Maret 2019 dapat diketahui bahwa siswa mengalami kesulitan dalam menyelesaikan soal-soal dengan tipe penyelesaian masalah matematis dan menerjemahkan soal kehidupan kontekstual ke model matematika, terutama pada materi yang bersifat abstrak. Berdasarkan nilai ulangan harian pada materi barisan dan deret, rata-rata nilai dari 5 kelas hanya 53\% siswa yang mencapai Kriteria Ketuntasan Minimal. Berdasarkan hal tersebut, disimpulkan bahwa siswa sulit memahami konsep-konsep matematika karena konsepkonsep matematika tersebut bersifat abstrak. Selain itu interaksi dalam proses pembelajaran masih rendah, kebanyakan siswa tidak mau bertanya apabila ada materi yang belum sepenuhnya mengerti, sehingga guru sulit memahami kemampuan penyelesaian masalah matematis siswa terhadap konsep matematika yang mereka pelajari.

Berdasarkan uraian yang dikemukakan, peneliti tertarik mendeskripsikan bagaimana disposisi matematis siswa SMK berdasarkan langkah-langkah penyelesaian masalah menurut teori Polya bermedia lembar kerja siswa pada materi barisan dan deret. Karena itu diambil judul "Disposisi Matematis Siswa SMK berdasarkan langkah-langkah penyelesaian masalah Polya".

Tujuan penelitian ini adalah mendeskripsikan disposisi matematis siswa SMK berdasarkan langkah-langkah penyelesaian Polya dengan harapan dapat membantu guru serta siswa dalam pemahaman konsep barisan dan deret dengan media yang ada di sekitar.

NCTM [1] menyebutkan, disposisi matematis yaitu suatu keterkaitan terhadap pembelajaran matematika sebagai suatu kecenderungan untuk berpikir dan bertindak positif. Killpatrick, Swafford dan Findel dalam Hendriana dkk [3] mengemukakan disposisi matematis adalah sikap positif serta kebiasaan untuk melihat matematika sebagai sesuatu yang logis, berguna dan berfaedah.

Penyelesaian masalah adalah salah satu tujuan pembelajaran matematika yang diharapkan dapat dilakukan siswa secara benar dan tepat yang dikembangkan pada kurikulum KTSP atau pun Kurikulum 2013. Sesuai dengan standar pembelajaran matematika yang 
ditetapkan NTCM [1] bahwa salah satu kemampuan dasar yang perlu dikuasai dan dikembangkan peserta didik yakni kemampuan penyelesaian masalah atau problem solving.

Menurut Polya, langkah-langkah penyelesaian masalah dalam empat tahap, yaitu : (1) Pemahaman masalah (2) Menemukan suatu rencana, (3) Melaksanakan rencana, (4) Evaluasi.

\section{Metode Penelitian}

Penelitian ini menggunakan pendekatan penelitian kualitatif. Metode penelitian yang digunakan adalah metode penelitian deskriptif. Menurut Marlina dan Danica [4], metode analisis deskriptif merupakan metode yang digunakan untuk menganalisis data-data yang tersedia dan diolah sehingga diperoleh gambaran yang jelas mengenai fakta fakta dan hubungan antar fenomena yang diteliti. Penelitian deskriptif dipilih karena penelitian ini bertujuan untuk mendeskripsikan disposisi matematis siswa dengan pedoman langkah Polya.

Penelitian dilakukan di SMK Hidayatus Sholihin. Subjek penelitian adalah siswa kelas XI jurusan Teknik Komputer dan Jaringan yang telah memperoleh materi barisan dan deret ketika kelas X sebanyak 2 siswa dengan pertimbangan siswa yang dijadikan subjek adalah siswa yang komunikatif menurut guru. Tahapan penelitian dirincikan sebagai berikut : (1) pemberian lembar kerja siswa sebagai soal tes penyelesaian masalah matematika; (2)menganalisis data; (3)menarik kesimpulan dari data yang diperoleh. Jenis data yang diperoleh adalah data kualitatif yang diperoleh dari hasil tes berdasarkan triangulasi teknik melalui lembar kerja siswa dan lembar wawancara.

Indikator tes ini terdiri dari aspek disposisi matematis serta langkah penyelesaian masalah Polya. yang akan membagi disposisi matematis siswa dalam tiga kelompok, yakni tinggi, sedang dan rendah. Indikator tersebut antara lain: (1) siswa dapat memahami masalah yang diberikan dengan percaya diri, (2) siswa dapat membuat rencana penyelesaian dengan fleksibel dalam menggali ide matematis, (3) siswa melaksanakan rencana penyelesaian dengan tekun (4) siswa mengecek kembali hasil penyelesaian dengan memiliki kecenderungan untuk memonitor, merasa ingin tahu dengan penalaran dalam penyelesaian masalah matematika.

\section{Hasil Penelitian}

Berdasarkan data tes disposisi matematis dan penyelesaian masalah matematika mengenai konsep barisan dan deret bermedia batik khas Kediri yang diperoleh dari subjek diperoleh hasil :

a. Analisis Langkah Penyelesaian Masalah Polya Siswa SMK

Berdasarkan hasil analisis langkah penyelesaian masalah yang telah valid pada tabel 1 dengan persentase 1-100 sebagai berikut :

Tabel 1. Analisis Langkah Penyelesaian Masalah Polya

Kategori Disposisi

Matematis Siswa Kode Siswa Jumlah \% SMK

\begin{tabular}{cccc}
\hline Tinggi & - & - & - \\
\hline Sedang & A1 & 1 & $75 \%$ \\
\hline Rendah & M1 & 1 & $50 \%$ \\
\hline
\end{tabular}

b. Analisis Disposisi Matematis Siswa SMK Berdasarkan hasil analisis disposisi matematis yang telah valid pada valid pada tabel 2 dengan persentase 1-100 sebagai berikut : 
Tabel 2. Analisis Skala Disposisi Matematis Siswa SMK

\begin{tabular}{|c|c|c|c|}
\hline $\begin{array}{c}\text { Kategori } \\
\text { Disposisi } \\
\text { Matematis Siswa } \\
\text { SMK }\end{array}$ & Kode Siswa & Jumlah & $\%$ \\
\hline Tinggi & - & - & - \\
\hline Sedang & A1 & 1 & $50 \%$ \\
\hline Rendah & M1 & 1 & $50 \%$ \\
\hline
\end{tabular}

c. Disposisi Matematis Siswa SMK Berdasarkan Langkah Penyelesaian Masalah Polya

Berdasarkan hasil analisis disposisi matematis berdasarkarkan langkah-langkah penyelesaian masalah bermedia batik khas Kediri pada table 3 telah valid dengan presentase 1-100 sebagai berikut :

Tabel 3. Analisis Disposisi Matematis Siswa SMK Berdasarkan Langkah Penyelesaian Masalah Polya Bermedia Batik Khas Kediri

\begin{tabular}{cccc}
$\begin{array}{c}\text { Kategori Disposisi } \\
\text { Matematis Siswa } \\
\text { SMK }\end{array}$ & Kode Siswa & Jumlah & $\%$ \\
& & & \\
\hline Tinggi & - & - & - \\
\hline Sedang & A1 & 1 & $60 \%$ \\
\hline Rendah & M1 & 1 & $50 \%$ \\
\hline
\end{tabular}

Kemampuan Disposisi Matematis berdasarkan hasil tes yang telah dilakukan masuk dalam golongan sedang dan rendah.

Kemampuan disposisi matematis siswa berdasarkan langkah penyelesaian menurut hasil sedang, karena siswa yang memiliki disposisi matematis yang sedang cenderung dalam langkah-langkah penyelesaian masalah juga sedang dan rendah.

Dengan demikian langkah penyelesaian masalah dapat menunjang disposisi matematis siswa. Antara satu siswa dengan yang lain memiliki kemampuan yang berbeda.

\section{Penutup}

Berdasarkan hasil dan pembahasan yang termuat dalam penelitian ini, secara umum dapat disimpulkan :

a. Disposisi matematis siswa berdasarkan langkah penyelesaian masalah berbeda.

b. disposisi matematis berdasarkan langkah penyelesaian masalah Polya, siswa tergolong sedang dan rendah, yaitu bagi siswa kategori sedang, siswa mampu memahami masalah yang diberikan. Siswa mampu menyusun rencana untuk menyelesaikan masalah. Namun belum mampu menyelesaikan masalah sesuai rencana. Untuk siswa kategori rendah, siswa mampu memahami masalah yang diberikan namun untuk menyusun rencana dan menyelesaikan masalah sesuai rencana siswa belum mampu.

\section{Referensi}

[1] NCTM. 2000.Principle and Standards for School mathematics. USA: NCTM

[2] Harususilo, Y.E. 8 Mei 2018. Ini 2 Faktor Penyebab Nilai UN SMA Menurun. Tersedia https:/edukasi.kompas.com/read/2018/05/ 08/20070771/ini-2-faktor-penyebab-nilaiun-sma-menurun. diakses 9 Mei 2019

[3] Hendriana, H., Rohaeti, E. E., \& Sumarmo, U. (2017). Hard Skills dan Soft Skills Matematik Siswa. Bandung: Refika Aditama.

[4] Marlina, L., \& Danica, C. (2009). Analisis Pengaruh Cash Position. Debt To Equity Ratio, Dan Return On Assets Terhadap Divident Payout Ratio. Jurnal Manajemen Bisnis. Vol. 2(1),pp. 1-6. 